\title{
Deregulation of apoptosis-related genes is associated with PRV1 overexpression and JAK2 V617F allele burden in Essential Thrombocythemia and Myelofibrosis
}

Raquel Tognon ${ }^{1}$, Elainy PL Gasparotto ${ }^{1}$, Renata P Neves ${ }^{1}$, Natália S Nunes ${ }^{1}$, Aline F Ferreira', Patrícia VB Palma², Simone Kashima², Dimas T Covas ${ }^{2,5}$, Mary Santana ${ }^{3}$, Elizabeth X Souto ${ }^{3}$, Maria Aparecida Zanichelli ${ }^{4}$, Belinda P Simões ${ }^{5}$, Ana Maria de Souza ${ }^{1}$ and Fabíola A Castro ${ }^{1,6^{*}}$

\begin{abstract}
Background: Essential Thrombocythemia (ET) and Primary Myelofibrosis (PMF) are Chronic Myeloproliferative Neoplasms (MPN) characterized by clonal myeloproliferation/myeloaccumulation without cell maturation impairment. The JAK2 V617F mutation and PRV1 gene overexpression may contribute to MPN physiopathology. We hypothesized that deregulation of the apoptotic machinery may also play a role in the pathogenesis of ET and PMF. In this study we evaluated the apoptosis-related gene and protein expression of BCL2 family members in bone marrow $\mathrm{CD}_{3} 4^{+}$hematopoietic stem cells (HSC) and peripheral blood leukocytes from ET and PMF patients. We also tested whether the gene expression results were correlated with JAK2 V617F allele burden percentage, PRV1 overexpression, and clinical and laboratory parameters.

Results: By real time PCR assay, we observed that $A 1, M C L 1, B I K$ and $B I D$, as well as $A 1, B C L W$ and $B A K$ gene expression were increased in ET and PMF CD34 ${ }^{+}$cells respectively, while pro-apoptotic BAX and anti-apoptotic $B C L 2$ mRNA levels were found to be lower in ET and PMF CD34 ${ }^{+}$cells respectively, in relation to controls. In patients' leukocytes, we detected an upregulation of anti-apoptotic genes $A 1, B C L 2, B C L-X L$ and $B C L W$. In contrast, pro-apoptotic BID and $B I M_{E L}$ expression were downregulated in ET leukocytes. Increased BCL-X protein expression in PMF leukocytes and decreased BID protein expression in ET leukocytes were observed by Western Blot. In ET leukocytes, we found a correlation between JAK2 V617F allele burden and BAX, BIK and BAD gene expression and between $A 1, B A X$ and $B I K$ and $P R V 1$ gene expression. A negative correlation between PRV1 gene expression and platelet count was observed, as well as a positive correlation between PRV1 gene expression and splenomegaly.
\end{abstract}

Conclusions: Our results suggest the participation of intrinsic apoptosis pathway in the MPN physiopathology. In addition, PRV1 and JAK2 V617F allele burden were linked to deregulation of the apoptotic machinery.

Keywords: Chronic Myeloproliferative Neoplasms, Apoptosis, JAK2 V617F allele burden, PRV1 , BCL2 family members

\footnotetext{
* Correspondence: castrofa@fcfrp.usp.br

'Department of Clinical, Toxicological and Bromatological Analysis, University of São Paulo, Ribeirão Preto School of Pharmaceutical Sciences, Ribeirão Preto, Brazil

Full list of author information is available at the end of the article
} 


\section{Background}

Essential Thrombocythemia (ET) and Primary Myelofibrosis (PMF) are disorders classified as Philadelphia chromosome-negative Myeloproliferative Neoplasms (MPN) [1]. ET is a clonal disease characterized by an increase in the platelet count associated with bone marrow megakaryocyte hyperplasia. Thrombosis and hemorrhagic events are the main co-morbities in ET patients. PMF is characterized by bone marrow fibrosis, as well as peripheral blood findings such as anemia, leukoerythroblastosis and the presence of dacryocytes in peripheral blood [2].

The JAK2 V617F mutation, which leads to constitutive JAK2 activation, was shown to play an important role in MPN pathogenesis, and is found in $95 \%$ of Polycythemia Vera (PV) patients and in at least $50 \%$ of ET and PMF patients [3]. Constitutive JAK2 activation triggers several signaling pathways linked to cell survival and proliferation promoting myeloproliferation and resistance to cell death [4-8]. Other mutations have recently been described in ET and PMF patients, such as mutations in $J A K 2$ exon 12 and in the TET2, CBL, MPL and AXSL genes [9-13]. Several studies suggest an association between MPN clinical features and the JAK2 V617F allele burden [14]. Although this knowledge and the identification of these additional mutations greatly enhanced our understanding of MPN physiopathology, a complete understanding of the cellular and molecular mechanisms involved is still lacking.

Another relevant molecular alteration described in MPN patients is the overexpression of $P R V 1$, a surface receptor from hematopoietic cells associated with cell proliferation [15] related to JAK/STAT and SRC kinase pathways [16]. PRV1 overexpression was initially described in PV patients and in some cases of ET, but was not found elevated in other malignant hematological diseases such as Chronic Myeloid Leukemia (CML) $[15,17,18]$. Considering that $P R V 1$ gene expression is deregulated in MPN, it has been suggested that it may be used as a molecular marker in the diagnosis of these diseases [19]. Literature also supports the hypothesis that PRV1 overexpression contributes to MPN physiopathology, considering that there are studies showing a correlation between PRV1 expression and patients' clinical and laboratory features [15].

The apoptosis process may be triggered by two major pathways: the extrinsic or death-receptors pathway, and the intrinsic or mitochondrial pathway. The intrinsic apoptosis pathway or mitochondrial pathway is triggered by several stimuli such as ultra violet radiation, growth factor/cytokine deprivation, chemotherapeutic agents, viral infection and other stress factors related to physical and chemical injuries [20]. This pathway is mainly regulated by BCL2 family members, classified as either anti-apoptotic (BCL2, BCL- $\mathrm{X}_{\mathrm{L}}, \mathrm{BCLW}, \mathrm{MCL} 1$ and $\mathrm{A} 1$ ) or pro-apoptotic (BAX, BAK, BAD, BID, BIM, Bok, BIK, BMF, BOO, BCL- $\mathrm{X}_{S}$, PUMA and NOXA) proteins [21]. The apoptotic process was found to be deregulated in several hematopoietic neoplasms, leading to resistance to therapy and progression of disease. Alterations in apoptosis have been described in CML, Myelodysplastic Syndrome (MDS), Acute Myeloid Leukemia (AML), PV, ET and PMF [20,22-24].

In this study we investigated the potential association between apoptosis deregulation, JAK2 mutation and PRV1 overexpression in ET and PMF patients. We focused on evaluating the expression of apoptosisrelated genes of the BCL2 family, JAK2 V617F allele burden and $P R V 1$ expression in ET and PMF in bone marrow $\mathrm{CD}_{4} 4^{+}$hematopoietic stem cells (HSC) and peripheral blood leukocytes from ET and PMF patients. The correlation between gene expression, JAK2 allele burden, clinical and laboratory parameters and $P R V 1$ expression were also assessed.

We observed a deregulation in the expression of most of the studied genes in bone marrow $\mathrm{CD}_{3} 4^{+}$cells and peripheral leukocytes from ET and PMF patients in comparison to controls. Furthermore, a correlation between $B A D, B A X$ and $B I K$ expression and JAK2 V617F allele burden as well as between $A 1, B A X$ and $B I K$ and $P R V 1$ expression was detected. A negative correlation between $P R V 1$ expression and platelet count was also observed, as well as a positive correlation between $P R V 1$ expression and splenomegaly.

\section{Subjects and methods}

\section{Patients and Controls}

We studied bone marrow CD34 ${ }^{+}$HSC and peripheral blood leukocytes from $26 \mathrm{ET}$ patients (5 male, 21 female, mean age: 60.2 years; range: $35-80 y)$ and 12 PMF patients ( 9 male, 3 female, mean age: 61.7 years, range: $41-80 y$ ), without treatment. The bone marrow control group was composed of 23 bone marrow donors from the Bone Marrow Transplantation Unit of the Clinical Hospital - University of São Paulo at the Ribeirão Preto School of Medicine, São Paulo, Brazil. This group included 12 male and 11 female, with a mean age of 35.9 years (range $14-54 \mathrm{y}$ ). We also collected peripheral blood samples from 37 individuals with similar age, skin color and gender (14 male, 23 female with mean age of 58.5 years, range $31-80 y$ ) for leukocyte isolation. This research was approved by the local ethics committees and the consent form was signed by the patients and volunteer controls. It was not possible to match the age and sex of bone marrow donors because the local ethics committees only permit 
bone marrow samples to be obtained from bone marrow donors during the bone marrow transplantation cell collection procedure.

\section{JAK2 V617F allele burden detection, platelet count and spleen size determination}

Detection of the JAK2 V617F mutation and the allele burden were determined as described in Tognon et al., 2011 [24], by real time allelic discrimination PCR assay. Platelets count from ET and PMF peripheral blood was determined by the Abbott Cell Dyn 3500SL Hematology Analyzer. Spleen size was determined by ultrasonography. In order to correlate gene expression and splenomegaly, we used the increase in centimeters $(\mathrm{cm})$ along the longer dimension of the patients' spleen, considering as reference, a value of $12 \mathrm{~cm}$.

\section{Cell Isolation, RNA extraction and cDNA synthesis}

Cell isolation, RNA extraction and cDNA synthesis were performed as described in Tognon et al., 2011 [24]. Briefly, bone marrow CD34 ${ }^{+}$HSC were separated using the Ficoll-Hypaque protocol followed by Miltenyi CD34 isolation kit MidiMacs CD34+ ${ }^{+}$Isolation Kit (MACS; Miltenyi Biotec, Bergisch Gladbach, Germany) and peripheral leukocytes were obtained by the HaesSteril method. Total RNA from CD $34^{+}$HSC and leukocytes was extracted according to the Trizol ${ }^{\mathrm{TM}}$ (Invitrogen Life Technologies, CarlsBAD, California, USA) method. One microgram of RNA was used to synthesize cDNA using the High Capacity ${ }^{\mathrm{TM}}$ Kit from Applied Biosystems Life Technologies (Foster City, California, USA).

\section{Quantification of apoptosis-related gene and PRV1 expression}

The expression of anti-apoptotic genes $A 1, M C L 1$, $B C L 2, B C L-X_{L}$ and $B C L W$ and pro-apoptotic genes $B A D, B A X, B A K, B I D, B I K$ and $B I M_{E L}$ was evaluated by real time PCR in duplicate. For gene expression quantification we used the SYBR Green PCR Master Mix Kit (Applied Biosystems) and specific oligonucleotides (Invitrogen Life Technologies) (Table 1) on the 7500 Real Time PCR System (Applied Biosystems Life Technology). The results were normalized by the geometric mean of the beta-actin and the GAPDH housekeeping genes expression and represented by $2^{-\Delta \Delta C t}$ as described by Tognon et al., 2011 [24].

The PRV1 gene was quantified by the TaqMan PCR Master Mix kit using TaqMan ${ }^{\circledR}$ Gene Expression Assay (PRV1 - Hs00360669_m1; GAPDH -Hs99999905_m1) on Mastercycler ${ }^{\circledR}$ ep Realplex (Eppendorf AG, Hamburg, Germany). For this gene, GAPDH was used as housekeeping gene.
Table 1 Real time PCR primer sequences

\begin{tabular}{|c|c|}
\hline Gene & Primer Sequence \\
\hline$\overline{A 1}$ & $\begin{array}{l}\text { F: GGC TGG CTC AGG ACT ATC } \\
\text { R: CCA GTT AAT GAT GCC GTC }\end{array}$ \\
\hline MCL1 & $\begin{array}{l}\text { F: AGA AAG CTG CAT CGA ACC AT } \\
\text { R: CC AGC TCC TAC TCC AGC AAC }\end{array}$ \\
\hline$B C L 2$ & $\begin{array}{l}\text { F: ACG AGT GGG ATG CGG GAG ATG TG } \\
\text { R: GCG GTA GCG GCG GGA GAA GTC }\end{array}$ \\
\hline$B C L W$ & $\begin{array}{l}\text { F: AGT TCG AGA CCC GCT TCC } \\
\text { R: CCC GTC CCC GTA TAG AGC }\end{array}$ \\
\hline$B C L-X_{L}$ & $\begin{array}{l}\text { F: CTG AAT CGG AGA TGG AGA CC } \\
\text { R: TGG GAT GTC AGG TCA CTG AA }\end{array}$ \\
\hline$B I D$ & $\begin{array}{l}\text { F: GCT TCC AGT GTA GAC GGA GC } \\
\text { R: GTG CAG ATT CAT GTG TGG ATG }\end{array}$ \\
\hline BIK & $\begin{array}{l}\text { F: TCT GCA ATT GTC ACC GGT TA } \\
\text { R: TTG AGC ACA CCT GCT CCT C }\end{array}$ \\
\hline$B I M_{E L}$ & $\begin{array}{l}\text { F: GCC CCT ACC TCC CTA CAG AC } \\
\text { R: AAG ATG AAA AGC GGG GAT CT }\end{array}$ \\
\hline$B A D$ & $\begin{array}{l}\text { F: CCG AGT GAG CAG GAA GAC TC } \\
\text { R: GGT AGG AGC TGT GGC GAC T }\end{array}$ \\
\hline BAK & $\begin{array}{l}\text { F: TCT GGC CCT ACA CGT CTA CC } \\
\text { R: ACA AAC TGG CCC AAC AGA AC }\end{array}$ \\
\hline$B A X$ & $\begin{array}{l}\text { F: CCC TाT TGC TTC AGG GTT TC } \\
\text { R: TCT TCT TCC AGA TGG TGA GTG }\end{array}$ \\
\hline$\beta$-actin & $\begin{array}{l}\text { F: GCC CTG AGG CAC TCT TCC A } \\
\text { R: CCA GGG CAG TGA TCT CCT TCT }\end{array}$ \\
\hline GAPDH & $\begin{array}{l}\text { F: GCCTCAAGATCATCAGCAATGC } \\
\text { R: CATGGACTGTGGTCATGAGTCCT }\end{array}$ \\
\hline
\end{tabular}

F: Forward Primer, R: Reverse Primer

\section{Western Blot}

One million leukocytes were lysated in $100 \mathrm{uL}$ of sample buffer (5\% mercaptoethanol, $4 \%$ sodium dodecyl sulfate - SDS, $20 \%$ glycerol and $100 \mathrm{mM}$ Tris-HCl-pH 6.8), boiled at $100^{\circ} \mathrm{C}$ for 5 minutes and kept at $-20^{\circ} \mathrm{C}$ until the Western-Blot analysis was performed. Twenty-five $\mathrm{ml}$ of patient and controls' lysate were loaded in polyacrilamide gel, the proteins were separated on 15\% SDSPAGE and transferred onto polyvinylidene difluoride (PVDF) membrane (Amersham, GE Healthcare Life Science). The membranes were incubated with the primary antibody anti-BCL- $\mathrm{X}_{\mathrm{L}}$ (1:200 dilution, $\mathrm{H}-62$, SC7195, Santa Cruz Biotechnology $\left.{ }^{\circledR}\right)$ or anti-BID (1:500 dilution, \# 611528, BD Pharmingen) diluted in TBSTween (20 mM Tris, $137 \mathrm{mM} \mathrm{NaCl}, 0.01 \%$ Tween-20) with $5 \%$ non-fat milk for 16 hours. As a control for sample loading, the blot was probed with anti- $\gamma$-tubulin (1:2000 dilution, T3320, Sigma-Aldrich). Horseradish peroxidase (HRP) conjugated secondary antibodies and ECL Plus ${ }^{\circledR}$ (Amersham, GE Healthcare Life Science) were used for protein expression detection. Protein expression was measured by densitometry analysis performed by ImageQuant TL (Image Analysis Software, 2005, Amersham). To express the proteins densitometry results, firstly we calculated the ratio between protein test IDV (Integrated density value) and tubulin IDV, and 
then we calculated the protein expression ratio between patient and controls (IDV of patients protein expression divided by controls protein expression).

\section{Statistical analysis}

The Mann-Whitney test (t-test, one-tailed) was used to compare the values of gene expression among the studied groups. The correlations between apoptosis-related gene expression, JAK2 allele burden and PRV1 gene expression were carried out by Spearman tests using Prisma 5.0 Software. A $p$ value $<0.05$ was taken as significant.

\section{Results}

Gene expression of apoptosis-related BCL2 family members is deregulated in ET and PMF patients Gene expression analysis in $\mathrm{CD} 34^{+} \mathrm{HSC}$ from ET patients showed an increased expression of anti-apoptotic genes $A 1$ and $M C L 1$ and of pro-apoptotic genes BID and BIK (median $=39.25,2.07,5.69$ and 2.99, respectively) in comparison to controls $(0.986,0.431,1.15$ and 1.36 , respectively) $(\mathrm{p}<0.0001, \mathrm{p}=0.0349, \mathrm{p}=0.0128$ and $\mathrm{p}=0.0279$, respectively) (Figure 1A-D). The mRNA level of the proapoptotic gene $B A X$ was found to be lower (0.19) in patients than controls $(5.08)(\mathrm{p}=0.0319)$ (Figure 1E).

In PMF CD34. ${ }^{+}$SC the anti-apoptotic genes $A 1$, $B C L W$ and pro-apoptotic $B A K$ expression were significantly increased (21.11, 1.55 and 11.67 , respectively) compared to controls $(0.99,1.01$ and 1.67 , respectively) $(\mathrm{p}=0.0002, \mathrm{p}=0.0125$ and $\mathrm{p}=0.0460$, respectively $)$ (Figure 1A, F and 1G). BCL2 mRNA levels were downregulated in these cells $(0.18)$ in comparison to controls (1.99) $(\mathrm{p}=0.0086)($ Figure $1 \mathrm{H})$.

In ET patients' leukocytes we found an overexpression of the anti-apoptotic genes $A 1, B C L 2, B C L-X_{L}$ and $B C L W(16.10,2.21,2.71$ and 2.21 , respectively) when compared with controls $(0.49,0.88,0.80$ and 1.06 ,

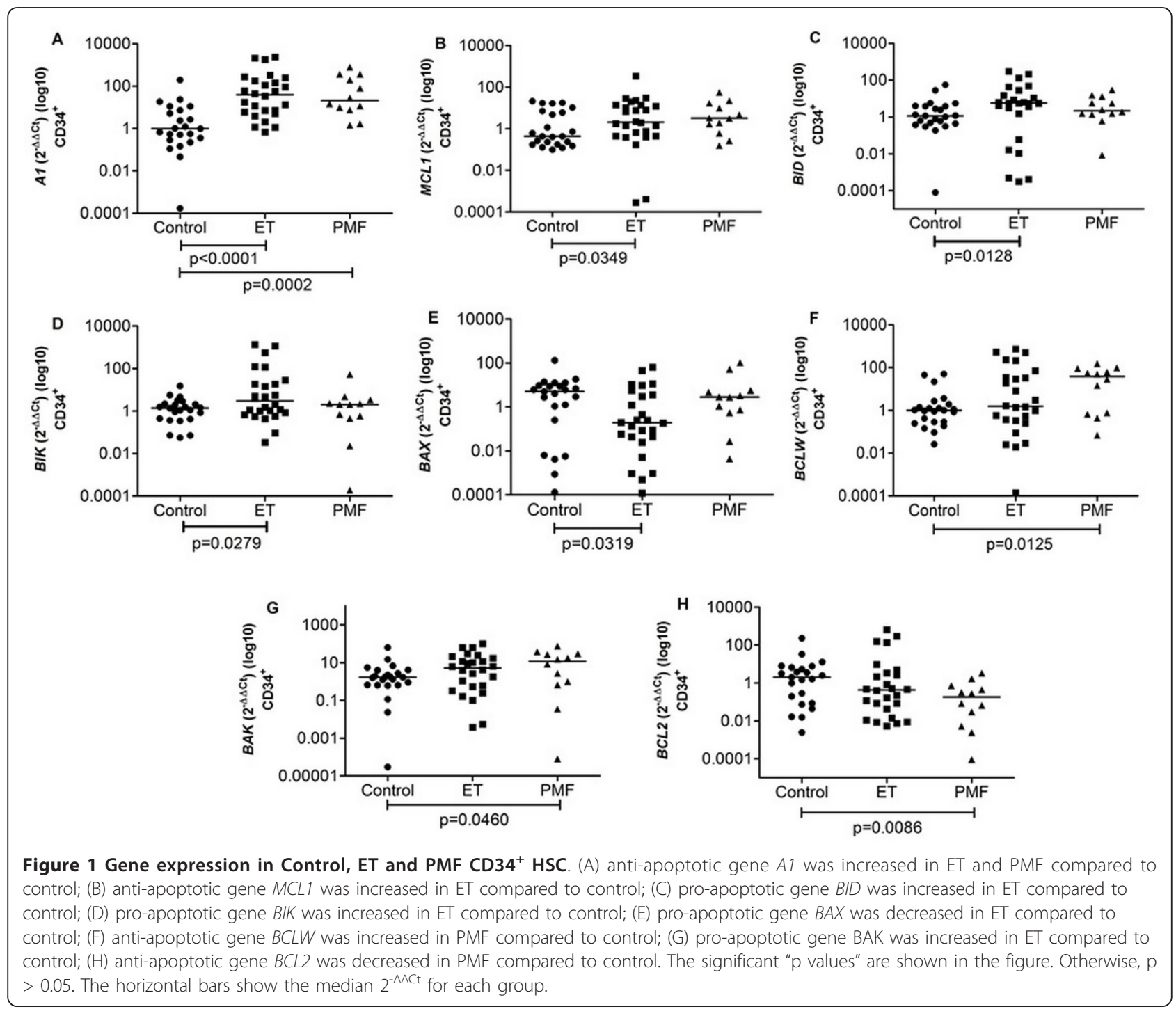




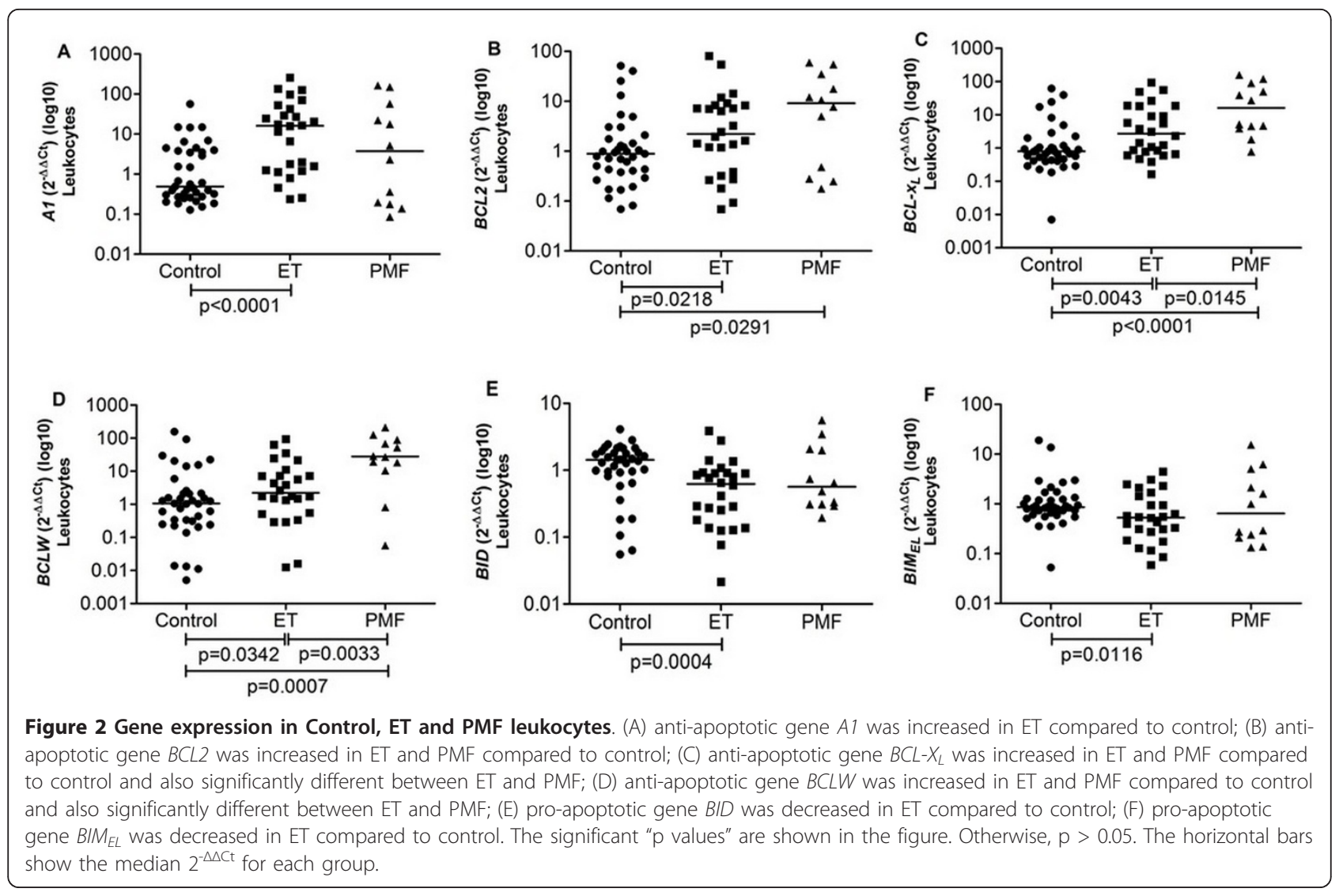

respectively) $(\mathrm{p}<0.0001, \mathrm{p}=0.0218, \mathrm{p}=0.0043$ and $\mathrm{p}$ $=0.0342$, respectively) (Figure 2A-D). The expression of pro-apoptotic genes $B I D$ and $B I M_{E L}$ was lower in ET leukocytes $(0.62,0.53)$ than in controls $(1.43,0.86)$ $(\mathrm{p}=0.0004, \mathrm{p}=0.0116)$ (Figure 2E, F).

In PMF leukocytes, $B C L 2, B C L-X_{L}$ and $B C L W$ expression were elevated $(9.17,16.10,27.86$, respectively) compared to controls $(0.88,0.80$ and 1.07 , respectively) $(\mathrm{p}=0.0291, \mathrm{p}<$ 0.0001 and $\mathrm{p}=0.0007$, respectively) (Figure $2 \mathrm{~B}, \mathrm{C}$ and $2 \mathrm{D}$ ).

Pro-apoptotic $B A D$ expression was found to be increased in ET and PMF leukocytes $(3.92,5.18)$ compared to controls $(0.63)(\mathrm{p}=0.0130, \mathrm{p}=0.0276)$ (data not shown).

There were no differences when we compared $B C L-X_{L}$ , $B A D$ and $B I M_{E L}$ expression between CD34 $4^{+}$cells from ET and PMF patients and controls, and this was also the case for MCL1, BID, BIK and BAX expression in leukocytes $(p>0.05)$. Furthermore, between ET and PMF leukocytes we only found a significant difference in $B C L W$ and $B C L-X_{L}$ expression ( $\mathrm{p}=0.0145, \mathrm{p}=$ 0.0033) (Figure $2 \mathrm{C}$ and $2 \mathrm{D}$ ).

\section{$\mathrm{BCL}-\mathrm{X}_{\mathrm{L}}$ and $\mathrm{BID}$ protein levels were different between controls and PMF and ET patients}

We detected an elevated level of anti-apoptotic BCL- $\mathrm{X}_{\mathrm{L}}$ in PMF leukocytes and a decreased expression of pro- apoptotic BID protein in ET leukocytes in comparison to control subjects (Figure 3A and 3B). Densitometry quantification by Integrated Density Value (IDV) showed that $B C L-X_{L}$ protein level is 2.4 times higher in PMF leukocytes than in controls, and BID protein in ET

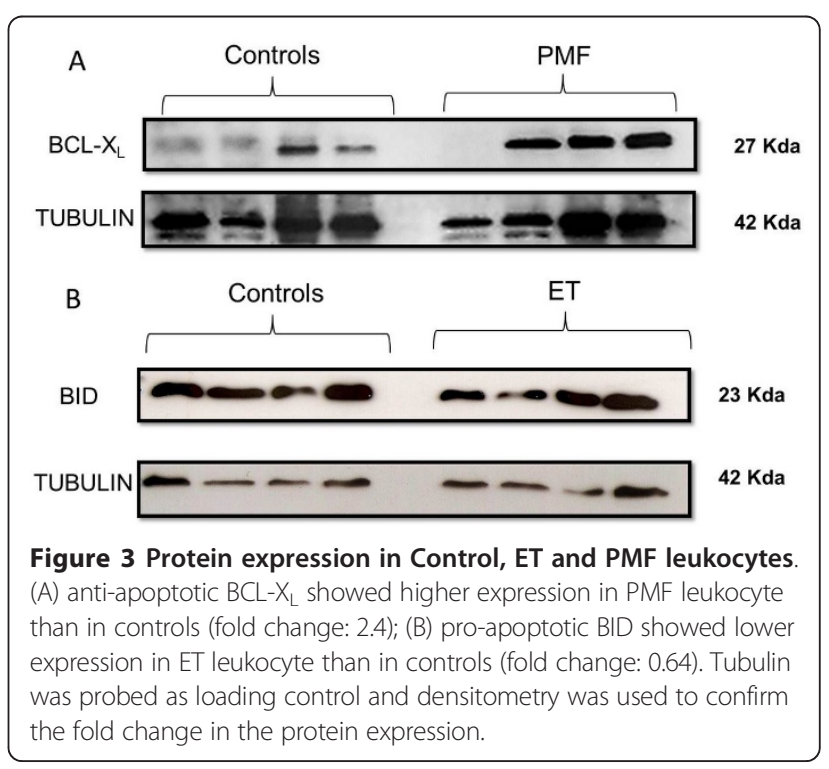


leukocytes is 0.64 fold decreased in relation to its expression in controls.

\section{JAK2 V617F allele burden is correlated with BAD, BAX and BIK expression in ET patients' leukocytes}

In JAK2 V617F-positive ET patients we detected lower levels of pro-apoptotic $B A X, B I K$ and $B A D$ expression (median: $0.26,0.45$ and 1.86, respectively) in leukocytes compared to JAK2 V617F-negative ET patients (1.59, 2.96 and 11.10, respectively) $(\mathrm{p}=0.0189, \mathrm{p}=0.0309$ and $\mathrm{p}=0.0055$, respectively) (Figure $4 \mathrm{~A}-\mathrm{C}$ ). In addition, $B A X, B I K$ and $B A D$ expression were negatively correlated with JAK2 V617F allele burden $(B A X: \mathrm{r}=-0.4522$; $\mathrm{p}=0.0102 ; B I K: \mathrm{r}=-0.4067, \mathrm{p}=0.0196 ; B A D: \mathrm{r}=$ -0.5966, $\mathrm{p}=0.0006$ ) in ET (Figure 4D-F).

PRV1 overexpression is correlated with A1, BIK and BAX gene expression, JAK2 V617F mutation, platelet count and splenomegaly

We observed that PRV1 was overexpressed in ET (3.04) and PMF (5.12) leukocytes in comparison to controls (0.93) $(\mathrm{p}=0.0011$ and $\mathrm{p}=0.0009)$ (Figure 5A). In ET leukocytes we also found that $P R V 1$ expression was positively correlated with $A 1$ expression ( $\mathrm{r}=0.3409, \mathrm{p}=0.0442)$, and negatively correlated with expression of $B A X(\mathrm{r}=-$ $0.3791, \mathrm{p}=0.0281)$ and $B I K(\mathrm{r}=-0.5009, \mathrm{p}=0.0046)$ (Figure 5B-D). Moreover, PRV1 expression was positively correlated with $B C L W(\mathrm{r}=0.6503, \mathrm{p}=0.0110)$ expression in PMF patients' leukocytes (Figure $5 \mathrm{E}$ ).
We detected a positive correlation between PRV1 expression and JAK2 V617F mutation allele burden in ET and PMF patients and this result corroborates the literature concerning the association between $P R V 1$ and JAK2 V617F described in murine myeloid cells [25] and PV patients [26]. Leukocytes from ET patients harboring the JAK2 V617F mutation showed higher expression of PRV1 (median $=4.88)$ in comparison to those negative for the JAK2 V617F mutation (1.91) ( $\mathrm{p}=0.0074)$ (Figure 6A) and, consequently, a positive correlation between PRV1 expression and JAK2 V617F allele burden was observed in ET patient leukocytes $(\mathrm{r}=0.4785 ; \mathrm{p}=0.0067)$ (Figure 6B).

Furthermore, $P R V 1$ expression was negatively correlated with platelet count in ET $(r=-0.3799, \mathrm{p}=0.0278)$ (Figure 7A) and PMF patients $(\mathrm{r}=-0.6713, \mathrm{p}=0.0084$ ) (Figure $7 \mathrm{~B}$ ), and $P R V 1$ expression in PMF leukocytes showed a positive correlation with the increase of the spleen size in centimeters (splenomegaly) $(r=0.6150$, $\mathrm{p}=0.0220)$ (Figure 7C).

\section{Discussion}

Our results indicate a deregulated expression of genes related to the intrinsic apoptosis pathway in $\mathrm{CD} 34^{+}$ HSC and peripheral leukocytes from ET and PMF patients.

Our hypothesis was that higher expression levels of anti-apoptotic genes may contribute to the myeloaccumulation in ET and PMF. In support of this notion, in this study we found increased expression of $A 1, M C L 1$,

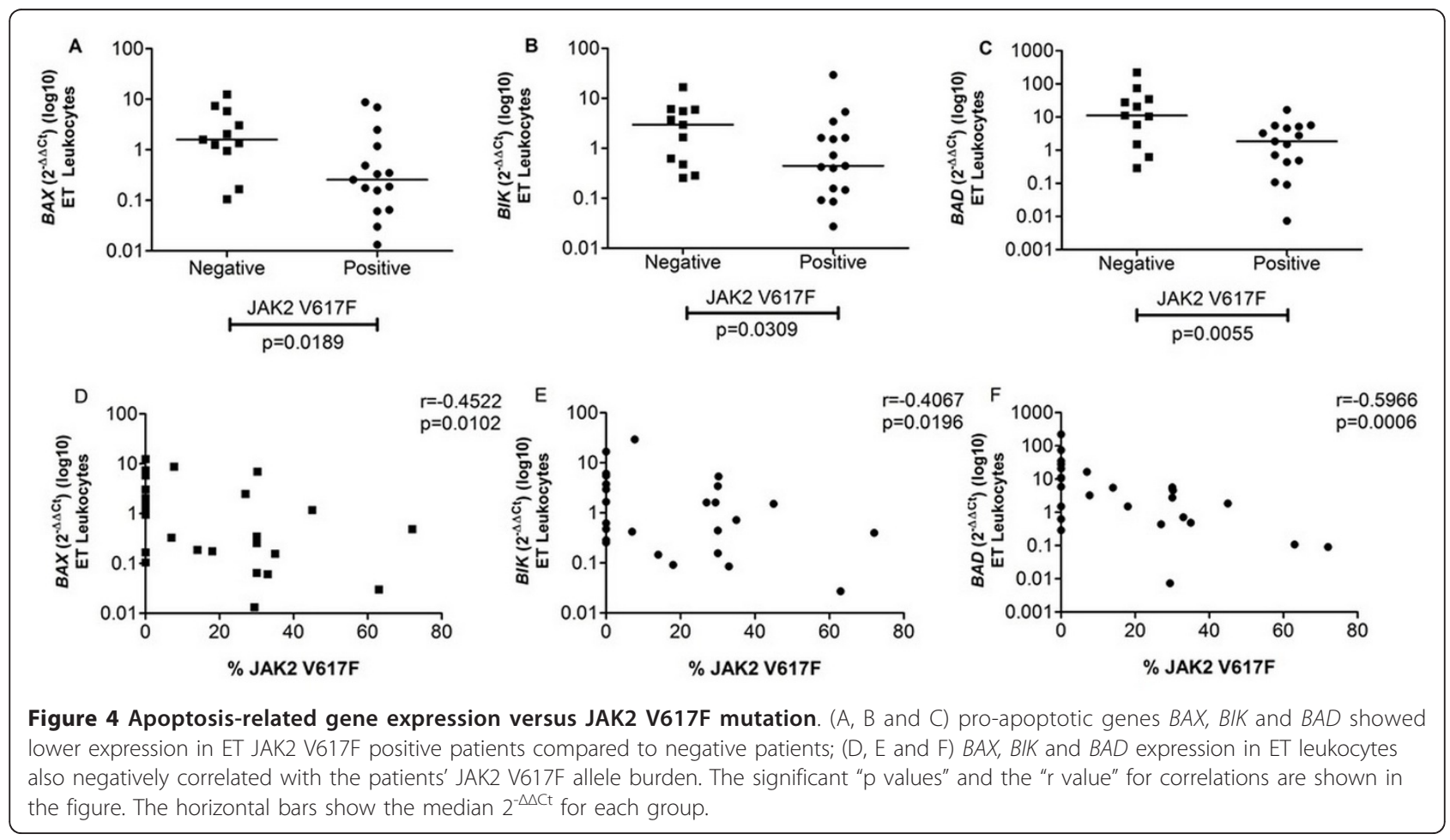




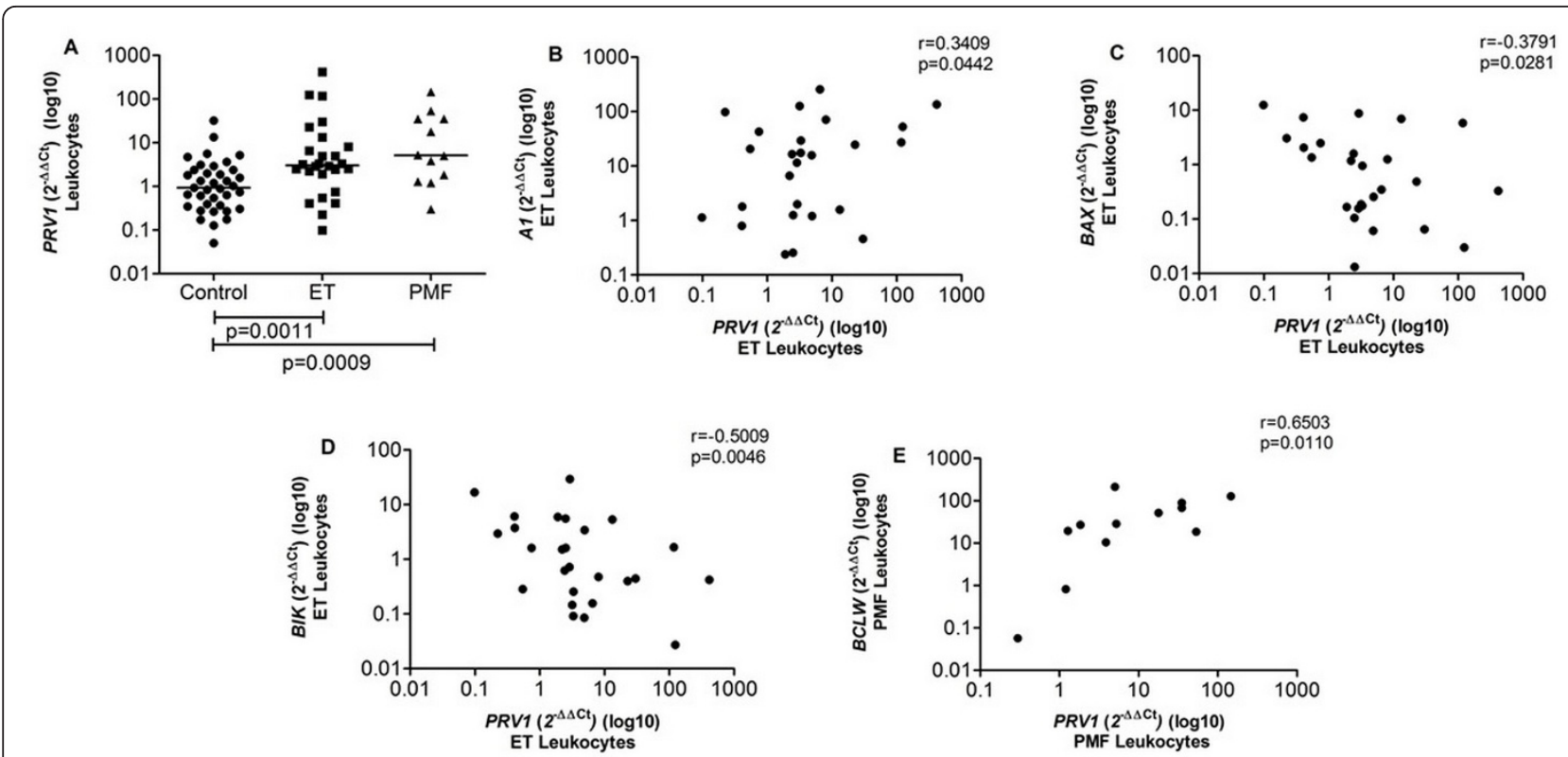

Figure 5 PRV1 gene expression in Control, ET and PMF leukocytes and PRV1 expression versus gene expression. (A) PRV1 expression was significantly elevated in ET and PMF leukocytes; (B) anti-apoptotic gene A1 showed positive correlation with PRV1 expression in ET leukocytes; (C and D) pro-apoptotic genes BAX and BIK showed negative correlation with PRV1 expression in ET leukocytes; (E) anti-apoptotic gene BCLW showed positive correlation with PRV1 expression in PMF leukocytes. The significant " $\mathrm{p}$ values" are shown in the figure. Otherwise, $\mathrm{p}$ $>0.05$. The horizontal bars show the median $2^{-\Delta \Delta C t}$ for each group.

$B C L W$ and $B C L-X_{L}$ genes in ET and PMF patients compared to controls. Importantly, as previously described by our group, the cells from MPN patients are resistant to apoptosis induced by different drugs (actinomycin D, teniposide, etoposide, cytarabin, and staurosporin) [24]. These observations, and our findings in the present investigation, support our hypothesis that deregulated expression of apoptosis-related genes is linked to myeloaccumulation and pathogenesis in ET and PMF.

The BCL2 family proteins have a central role in the process of apoptosis control. The A1, BCL2, BCLW, $B C L-X_{L}$ and MCL1 BCL2-family members encode antiapoptotic molecules, while BAD, BAX, BAK, BID, BIK,
BOK, BOO, PUMA, NOXA and BIM $\mathrm{EL}_{\mathrm{L}}$ encode proapoptotic molecules, all of them involved in the mitochondrial apoptosis pathway [21].

A1 (bfl1) expression is detected in several tissues such as hematopoietic and endothelial cells [27]. A1 gene transcription is dependent on the NF-kB pathway and its overexpression has been reported in Chronic Lymphocytic Leukemia (CLL), particularly in CLL patients who do not respond to therapy [27].

$B C L 2$ is an oncogene, which was first identified in Non-Hodgkin lymphoma B-cells and this gene is a pivotal molecule in the mitochondrial apoptosis pathway. Castro et al. (2005) described in the American Society
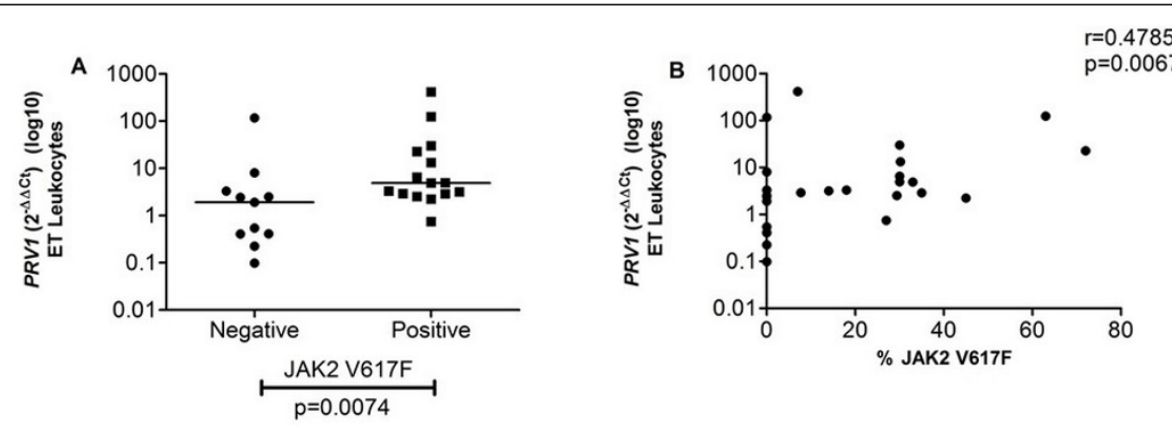

Figure 6 PRV1 expression versus JAK2 V617F mutation. (A) PRV1 expression was higher in ET JAK2 V617F positive patients than in JAK2 V617F negative patients; (B) a positive correlation between PRV1 expression in ET leukocytes and JAK2 V617F allele burden percentage was detected. The significant " $p$ values" and the " $r$ value" for correlations are shown in the figure. 


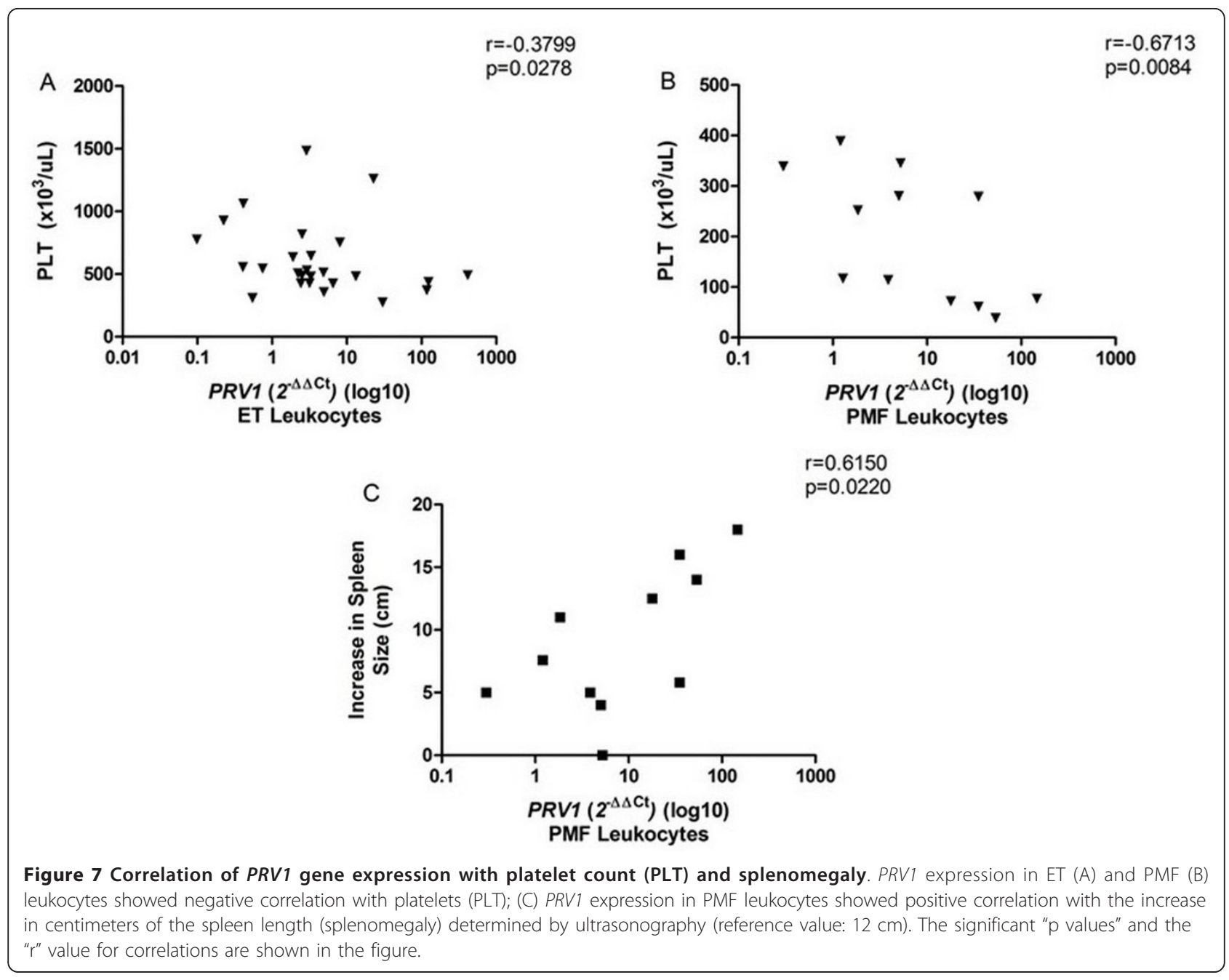

Hematology Congress [28] a decrease in $B C L 2$ expression and an increase in $B C L-X_{L}, B C L W, A 1, M C L 1$ and cflip expression in CML and they also demonstrated that this profile of expression was correlated with CML progression. Furthermore, many publications have shown that in neoplasms such as breast or stomach cancer, high levels of BCL2 proteins were associated with a worse prognosis [29].

Deregulation of $M C L 1$ expression was described in hepatocellular carcinoma [30] and in multiple myeloma [31]. Furthermore, the expression of this gene was also found to be correlated with prognosis in multiple myeloma [31]. Such deregulated expression was also verified in bone marrow blasts from patients with MDS [22]. Del Poeta et al. reported increased levels of $B C L 2, B C L$ $X_{L}$ and $M C L 1$ expression in AML [23] and Aichberger et al. showed that MCL1 is a BCR-ABL target gene in CML [32].

Among the pro-apoptotic proteins of the BCL2 family, $B A X$ has a crucial role in apoptosis and the lack of $B A X$ leads to apoptosis impairment and facilitates the development of B-cell lymphoma by c-Myc stimulation [33].

Regarding MPN pathophysiology, Zhang et al. [34] demonstrated that $\mathrm{BCL}-\mathrm{X}_{\mathrm{L}}$ is down-regulated early during in vitro differentiation of megakaryocytes from ET patients and this might reflect an early entry of megakaryocytes into a degenerating mature stage [34]. There is little data in the literature regarding apoptosis deregulation in PMF. On one hand, Mesa et al. (2006) showed that the levels of the anti-apoptotic and pro-apoptotic $B A X, B A K, B I M$ and $B m f$ were not different between PMF and controls [35]. On the other hand, it was demonstrated that JAK2 inhibition in a cellular model of MPN (JAK2 V617F positive cell lineage) triggers BIM activation and leads to enhanced sequestration of MCL1, furthermore, BCL- $\mathrm{X}_{\mathrm{L}}$ and MCL1 depletion by RNAi was sufficient to compromise JAK2 V617F mutant cell viability and sensitized the cells to JAK2 inhibition, indicating an association between these apoptosis-related molecules and the aberrant JAK2 signaling in these cells [36]. 
It has been described that BCL2 family proteins interact with each other to control the intrinsic apoptosis pathway [37]. The balance among the activities of these proteins is very important to tightly control the apoptosis process [38]. The MPN patients enrolled in this study showed overexpression of several antiapoptotic genes such as $A 1$ and MCL1 but also overexpression of some pro-apoptotic genes such as $B I K, B I D$ and $B A K$ in $C D 34^{+}$cells. Furthermore, in $\mathrm{CD} 34^{+}$cells we observed a downregulation of $B A X$ and $B I D$, and $B I M_{E L}$ levels were found reduced in ET leukocytes. Therefore, we postulate that the balance among these BCL2 family members is disrupted, and may contribute to the myeloaccumulation in these patients due to the increase in cell survival.

In addition, we found that mRNA levels of pro-apoptotic $B A X, B A D$ and $B I K$ mRNAs were lower in JAK2 V617F-positive patients than in those negative, and also presented a negative correlation with the JAK2 V617F allele burden. Some reviews published in the literature have already pointed out and discussed the relationship between constitutively activated JAK2/STAT signaling and deregulation of apoptosis-related genes in CML and human tumor cell lines $[39,40]$.

Moreover, we analyzed PRV1 mRNA expression and the correlation with JAK2 V617F mutation, and with clinical laboratorial data in leukocytes from control, ET and PMF patients. PRV1 is a hematopoietic cell surface receptor that has been shown to transduce intracellular signals leading to proliferation, involving JAK2 and Src kinases [16]. $P R V 1$ is overexpressed in MPN patients $[15,19,41,42]$ and seems to be associated with PV disease phenotype characterized by high erythrocyte and low platelet counts [15]. These studies also described a correlation between $P R V 1$ expression and the JAK2 V617F allele burden, as well as between $P R V 1$ overexpression and elevated JAK2 tyrosine kinase activity $[15,19,25,41,42]$.
In our results we detected a correlation between $P R V 1$ overexpression and the anti-apoptotic genes $A 1$ and $B C L W$, and the pro-apoptotic genes $B A X$ and $B I K$ expression. We also found a differential expression of $P R V 1$ according to JAK2 V617F status and a correlation between $P R V 1$ expression and platelet count in ET and PMF patients, as well as splenomegaly. Thus, our results suggest a link between $P R V 1$ and intrinsic apoptosis pathway regulation and are in good agreement with previous reports about the association of the JAK2 V617F mutation with deregulation of apoptosis and disease phenotype [25].

An illustrative overview of the gene expression results in CD $34^{+}$HSC and leukocytes from ET and PMF is shown in Figure 8 . This figure highlights the complexity of the apoptosis network in MPN patients. The analysis of the interaction of genes involved in the apoptotic machinery described here implies that apoptosis is deregulated and impaired in MPN patients since the majority of anti-apoptotic genes assessed are overexpressed, while concomitantly, some proapoptotic genes appear to be downregulated.

These observations are in line with previous results described by our group in Tognon et al. (2011) [24], which demonstrated that mononuclear cells from MPN patients are resistant to apoptosis, considering that patients' cells stimulated by numerous apoptotic inducers, such as actinomycin and cytarabin, showed less Annexin-V FITC staining compared to controls [24]. Therefore, deregulation of the intrinsic apoptosis pathway might contribute to ET and PMF physiopathology and myeloaccumulation.

MPN do not yet have a curative therapy so it is particularly relevant to consider the possibility of designing new drugs targeting apoptosis pathway. In this context, Zivny et al. (2010) reviewed this subject emphasizing the importance of developing new and more effective target cancer therapies with the potential of inhibiting the anti-apoptotic BCL2 family members or enhancing pro-

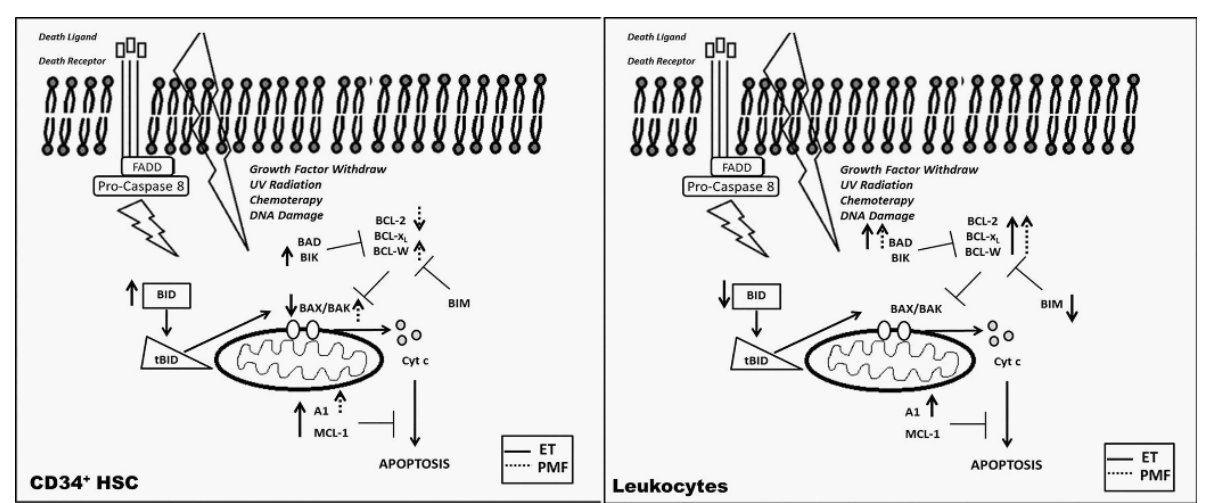

Figure 8 Overview of the BCL2 family gene expression results: (A) in CD34 ${ }^{+}$HSC and (B) leukocytes from patients with ET (continuous arrows) and PMF (stippled arrows). 
apoptotic proteins expression [20]. These approaches might impair evasion of tumor cell to apoptosis processes or might sensitize cells to apoptosis. Taken together our results suggest that ET and PMF treatment could not be restrict to JAK2 inhibitors, considering that there are other molecular mechanisms involved in MPN pathogenesis, in addition to JAK2 mutation. Maybe in the future, JAK2 inhibitor treatment must be associated with new target therapies, such as anti-apoptotic BCL2 family members' inhibitors or pro-apoptotic enhancers, for better patients ' response to therapy.

\section{Conclusion}

CD $34^{+}$HSC and leukocytes from ET and PMF patients displayed a deregulation in expression levels of BCL2 family members, which are correlated with JAK2 V617F mutation and PRV1 mRNA levels. Our findings suggest that these alterations may contribute to increased resistance to apoptosis and to myeloaccumulation in ET and PMF patients.

\section{Acknowledgements \\ We are really grateful to Dr. Thomas Radimerski from Novartis Institute for Biomedical Research (Basel, Switzerland) for reviewing and discussing the manuscript results. We are also grateful to Luciana Ambrosio for technical assistance. AFF, NSN and RT are recipients of a fellowship from the Fundação de Amparo à Pesquisa do Estado de São Paulo (FAPESP) (Process Numbers: 2008/52049-5, 2010/01756-3 and 2008/54387-5, respectively). EPLG, GLVO and RPN were recipients of fellowships from the Conselho Nacional de Desenvolvimento Científico e Tecnológico (CNPq). \\ This work was supported by FAPESP grants Numbers 2006/50094-8 and 2008/54387-5.}

\section{Author details}

'Department of Clinical, Toxicological and Bromatological Analysis, University of São Paulo, Ribeirão Preto School of Pharmaceutical Sciences, Ribeirão Preto, Brazil. 'Regional Blood Center of Ribeirão Preto, Clinical Hospital, University of São Paulo, Ribeirão Preto School of Medicine, Ribeirão Preto, Brazil. ${ }^{3}$ Brigadeiro Hospital of São Paulo, São Paulo, Brazil. ${ }^{4}$ Institute for Cancer Treatment in Children-ITACI, São Paulo, Brazil. ${ }^{5}$ Department of Clinical Medicine, University of São Paulo, Ribeirão Preto School of Medicine, Ribeirão Preto, Brazil. ${ }^{6}$ INCT-IF-CNPq.

\section{Authors' contributions}

RT designed and performed experiments, analyzed data and wrote the paper. EPLG, RPN, NSN, AFF and PVBP performed some of the cell isolation, RNA extraction and gene expression assays. MAZ, EXS, BPS and MS selected the patients included in this study and collected the bone marrow samples for $\mathrm{CD}_{4} 4^{+}$cell isolation. NSN, MAZ, DTC, AMS and SK performed real-time experiments, discussed the results and revised the paper. FAC conceived the project, created the study design, sought funding and wrote the paper. All authors critically reviewed the manuscript.

\section{Competing interests}

The authors declare that they have no competing interests.

Received: 28 November 2011 Accepted: 2 February 2012 Published: 2 February 2012

\section{References}

1. Tefferi A, Vardiman JW: Classification and diagnosis of myeloproliferative neoplasms: the 2008 World Health Organization criteria and point-ofcare diagnostic algorithms. Leukemia 2008, 22:14-22.
2. Anastasi J: The myeloproliferative neoplasms: insights into molecular pathogenesis and changes in WHO classification and criteria for diagnosis. Hematol Oncol Clin North Am 2009, 23:693-708.

3. Vainchenker W, Delhommeau F, Constantinescu SN, Bernard OA: New mutations and pathogenesis of myeloproliferative neoplasms. Blood 2011.

4. James C, Ugo V, Le Couédic JP, Staerk J, Delhommeau F, Lacout C, Garçon L, Raslova H, Berger R, Bennaceur-Griscelli A, Villeval JL, Constantinescu SN, Casadevall N, Vainchenker W: A unique clonal JAK2 mutation leading to constitutive signalling causes polycythaemia vera. Nature 2005, 434:1144-1148.

5. B Baxter EJ, Scott LM, Campbell PJ, East C, Fourouclas N, Swanton S, Vassiliou GS, Bench AJ, Boyd EM, Curtin N, Scott MA, Erber WN, Green AR: Acquired mutation of the tyrosine kinase JAK2 in human myeloproliferative disorders. Lancet 2005, 365:1054-1061.

6. Levine RL, Wadleigh M, Cools J, Ebert BL, Wernig G, Huntly BJ, Boggon TJ, Wlodarska I, Clark JJ, Moore S, Adelsperger J, Koo S, Lee JC, Gabriel S, Mercher T, D'Andrea A, Fröhling S, Döhner K, Marynen P, Vandenberghe $P$, Mesa RA, Tefferi A, Griffin JD, Eck MJ, Sellers WR, Meyerson M, Golub TR, Lee SJ, Gilliland DG: Activating mutation in the tyrosine kinase JAK2 in polycythemia vera, essential thrombocythemia, and myeloid metaplasia with myelofibrosis. Cancer Cell 2005, 7:387-397.

7. Kralovics R, Passamonti F, Buser AS, Teo SS, Tiedt R, Passweg JR, Tichelli A, Cazzola M, Skoda RC: A gain-of-function mutation of JAK2 in myeloproliferative disorders. N Engl J Med 2005, 352:1779-1790.

8. Zhao R, Xing S, Li Z, Fu X, Li Q, Krantz SB, Zhao ZJ: Identification of an acquired JAK2 mutation in polycythemia vera. J Biol Chem 2005, 280:22788-22792.

9. Scott LM, Tong W, Levine RL, Scott MA, Beer PA, Stratton MR, Futreal PA, Erber WN, McMullin MF, Harrison CN, Warren AJ, Gilland DG, Lodish HF, Green AR: JAK2 exon 12 mutations in polycythemia vera and idiopathic erythrocytosis. N Engl J Med 2007, 356:459-468.

10. Delhommeau F, Dupont S, Della Valle V, James C, Trannoy S, Massé A, Kosmider O, Le Couedic JP, Robert F, Alberdi A, Lécluse Y, Plo I, Dreyfus FJ, Marzac C, Casadevall N, Lacombe C, Romana SP, Dessen P, Soulier J, Viguié F, Fontenay $\mathrm{M}$, Vainchenker $\mathrm{W}$, Bernard AO: Mutation in TET2 in myeloid cancers. N Engl J Med 2009, 360:2289-2301.

11. Grand FH, Hidalgo-Curtis CE, Ernst T, Zoi K, Zoi C, McGuire C, Kreil S, Jones A, Score J, Metzgeroth G, Oscier D, Hall A, Brandts C, Serve H, Reiter A, Chase AJ, Cross NC: Frequent CBL mutations associated with $11 q$ acquired uniparental disomy in myeloproliferative neoplasms. Blood 2009, 113:6182-6192.

12. Pikman $Y$, Lee BH, Mercher T, McDowell E, Ebert BL, Gozo M, Cuker A, Wernig G, Moore S, Galinsky I, DeAngelo DJ, Clark JJ, Lee SJ, Golub TR, Wadleigh M, Gilliland DG, Levine RL: MPLW515L is a novel somatic activating mutation in myelofibrosis with myeloid metaplasia. PLOS Med 2006, 3:e270.

13. Carbuccia N, Murati A, Trouplin V, Brecqueville M, Adélaïde J, Rey J, Vainchenker W, Bernard OA, Chaffanet M, Vey N, Birnbaum D, Mozziconacci MJ: Mutations of ASXL1 gene in myeloproliferative neoplasms. Leukemia 2009, 23:2183-2186.

14. Larsen TS, Pallisgaard N, Møller MB, Hasselbalch HC: The JAK2 V617F allele burden in essential thrombocythemia, polycythemia vera and primary myelofibrosis-impact on disease phenotype. Eur J Haematol 2007, 79:508-515.

15. Griesshammer M, Klippel S, Strunck E, Temerinac S, Mohr U, Heimpel H, Pahl HL: PRV-1 mRNA expression discriminates two types of essential thrombocythemia. Ann Hematol 2004, 83:364-370.

16. Dillon M, Minear J, Johnson J, Lannutti BJ: Expression of the GPI-anchored receptor Prv-1 enhances thrombopoietin and IL-3-induced proliferation in hematopoietic cell lines. Leuk Res 2008, 32:811-819.

17. Temerinac S, Klippel S, Strunck E, Röder S, Lübbert M, Lange W, Azemar M, Meinhardt G, Schaefer HE, Pahl HL: Cloning of PRV-1, a novel member of the UPAR receptor superfamily, which is overexpressed in polycythemia rubra vera. Blood 2000, 95:2569-2576.

18. Klippel S, Strunck E, Temerinac S, Bench AJ, Meinhardt G, Mohr U, Leichtle R, Green AR, Griesshammer M, Heimpel H, Pahl HL: Quantification of PRV-1 mRNA distinguishes polycythemia vera from secondary erythrocytosis. Blood 2003, 102:3569-3574

19. Melis S, Vellinga S, Zachée P, Sierens AC, De Schouwer PJ: JAK2 V617F mutation and PRV-1 overexpression: relevance in the diagnosis of 
polycythaemia vera and essential thrombocythaemia. Acta Clin Belg 2009, 64:429-433.

20. Zivny J, Klener P, Pytlik R, Andera L: The role of apoptosis in cancer development and treatment: focusing on the development and treatment of hematologic malignancies. Curr Pharm Des 2010, 16:11-33.

21. Thomadaki H, Scorilas A: BCL2 family of apoptosis-related genes: functions and clinical implications in cancer. Crit Rev Clin Lab Sci 2006, 43:1-67.

22. Economopoulou C, Pappa V, Kontsioti F, Papageorgiou S, Kapsimali V, Papasteriadi C, Economopoulou P, Papageorgiou E, Dervenoulas J, Economopoulos T: Analysis of apoptosis regulatory genes expression in the bone marrow (BM) of adult de novo myelodysplastic syndromes (MDS). Leuk Res 2008, 32:61-69.

23. Del Poeta G, Bruno A, Del Principe MI, Venditti A, Maurillo L, Buccisano F, Stasi R, Neri B, Luciano F, Siniscalchi A, de Fabritiis P, Amadori S: Deregulation of the mitochondrial apoptotic machinery and development of molecular targeted drugs in acute myeloid leukemia. Curr Cancer Drug Targets 2008, 8:207-222.

24. Tognon R, Gasparotto EP, Leroy JM, Oliveira GL, Neves RP, Carrara ReC, Kashima S, Covas DT, Santana M, Souto EX, Zanichelli MA, Velano CE, Simões BP, Alberto FL, Miyashiro K, de Souza AM, Amarante-Mendes GP, de Castro FA: Differential expression of apoptosis-related genes from death receptor pathway in chronic myeloproliferative diseases. J Clin Pathol 2011, 64:75-82.

25. Mnjoyan Z, Yoon D, Li J, Delhommeau F, Afshar-Kharghan V: The effect of the JAK2 V617F mutation on PRV-1 expression. Haematologica 2006, 91:411-412.

26. Kralovics R, Teo SS, Buser AS, Brutsche M, Tiedt R, Tichelli A, Passamonti F, Pietra D, Cazzola M, Skoda RC: Altered gene expression in myeloproliferative disorders correlates with activation of signaling by the V617F mutation of Jak2. Blood 2005, 106:3374-3376

27. Olsson A, Norberg M, Okvist A, Derkow K, Choudhury A, Tobin G, Celsing F, Osterborg A, Rosenquist R, Jondal M, Osorio LM: Upregulation of bfl-1 is a potential mechanism of chemoresistance in B-cell chronic lymphocytic leukaemia. Br J Cancer 2007, 97:769-777.

28. Castro FA, Jacysyn JF, Ulbrich AG, Tobo PR, Lopes LR, Colassantti MD, Camanho D, Zanichelli MA, Hamerschlak N, Cavalheiro RC, Oliveira JSR, Amarante-Mendes GP: Overexpression of the Anti-Apoptotic Genes mcl-1, bcl-w, bcl-xL and a1 Is Correlated with Chronic Myelogenous Leukemia Progression and Resistance to Gleevec [abstract]. ASH Annual Meeting Abstracts 2005, 106:2880.

29. Frenzel A, Grespi F, Chmelewskij W, Villunger A: Bcl2 family proteins in carcinogenesis and the treatment of cancer. Apoptosis 2009, 14:584-596.

30. Fabregat I: Dysregulation of apoptosis in hepatocellular carcinoma cells. World J Gastroenterol 2009, 15:513-520.

31. Wuillème-Toumi S, Robillard N, Gomez P, Moreau P, Le Gouill S, AvetLoiseau H, Harousseau JL, Amiot M, Bataille R: Mcl-1 is overexpressed in multiple myeloma and associated with relapse and shorter survival. Leukemia 2005, 19:1248-1252

32. Aichberger $\mathrm{K}$, Mayerhofer M, Krauth MT, Skvara H, Florian S, Sonneck $K$, Akgul C, Derdak S, Pickl WF, Wacheck V, Selzer E, Monia BP, Moriggl R, Valent $P$, Sillaber $C$ : Identification of $\mathrm{mcl}-1$ as a BCR/ABL-dependent target in chronic myeloid leukemia (CML): evidence for cooperative antileukemic effects of imatinib and mcl-1 antisense oligonucleotides. Blood 2005, 105:3303-3311.

33. Eischen CM, Roussel MF, Korsmeyer SJ, Cleveland JL: Bax loss impairs Mycinduced apoptosis and circumvents the selection of p53 mutations during Myc-mediated lymphomagenesis. Mol Cell Biol 2001, 21:7653-7662.

34. Zhang L, Zhao H, Sun A, Lu S, Liu B, Tang F, Feng Y, Zhao L, Yang R, Han ZC: Early down-regulation of $\mathrm{BCl}-\mathrm{xL}$ expression during megakaryocytic differentiation of thrombopoietin-induced CD34+ bone marrow cells in essential thrombocythemia. Haematologica 2004, 89:1199-1206.

35. Mesa RA, Tefferi A, Lasho TS, Loegering D, McClure RF, Powell HL, Dai NT, Steensma DP, Kaufmann SH: Janus kinase 2 (V617F) mutation status, signal transducer and activator of transcription-3 phosphorylation and impaired neutrophil apoptosis in myelofibrosis with myeloid metaplasia. Leukemia 2006, 20:1800-1808.

36. Rubert J, Qian Z, Andraos R, Guthy DA, Radimerski T: Bim and Mcl-1 exert key roles in regulating JAK2V617F cell survival. BMC Cancer 2011, 11:24.
37. Chipuk JE, Moldoveanu T, Llambi F, Parsons MJ, Green DR: The BCL-2 family reunion. Mol Cell 2010, 37:299-310.

38. Chipuk JE, Green DR: How do BCL-2 proteins induce mitochondrial outer membrane permeabilization? Trends Cell Biol 2008, 18:157-164.

39. Battle TE, Frank DA: The role of STATs in apoptosis. Curr Mol Med 2002 2:381-392.

40. Turkson J: STAT proteins as novel targets for cancer drug discovery. Expert Opin Ther Targets 2004, 8:409-422.

41. Puigdecanet E, Espinet B, Villa O, Florensa L, Besses C, Serrano S, Solé F: Detection of abnormalities of PRV-1, TPO, and c-MPL genes detected by fluorescence in situ hybridization in essential thrombocythemia. Cancer Genet Cytogenet 2006, 167:39-42.

42. Johansson P, Andréasson B, Safai-Kutti $S$, Wennström L, Palmqvist $L$, Ricksten $A$, Lindstedt $G$, Kutti J: The presence of a significant association between elevated PRV-1 mRNA expression and low plasma erythropoietin concentration in essential thrombocythaemia. Eur J Haematol 2003, 70:358-362.

doi:10.1186/1756-8722-5-2

Cite this article as: Tognon et al: Deregulation of apoptosis-related genes is associated with PRV1 overexpression and JAK2 V617F allele burden in Essential Thrombocythemia and Myelofibrosis. Journal of Hematology \& Oncology 2012 5:2.

\section{Submit your next manuscript to BioMed Central and take full advantage of:}

- Convenient online submission

- Thorough peer review

- No space constraints or color figure charges

- Immediate publication on acceptance

- Inclusion in PubMed, CAS, Scopus and Google Scholar

- Research which is freely available for redistribution

Submit your manuscript at www.biomedcentral.com/submit
C Biomed Central 